\title{
Inkludering av minoritetsspråklige elever i kroppsøvingsfaget - utfordringer og strategier med utgangspunkt $i$ et lærerperspektiv
}

\author{
Pål Lagestad ${ }^{\star}$ og Ingvild Mestad \\ Nord universitet
}

\begin{abstract}
Sammendrag
Kunnskap om hvilke utfordringer kroppsøvingslærere opplever ved inkludering av minoritetsspråklige elever i kroppsøving, samt hvilke strategier erfarne kroppsøvingslærere benytter for en best mulig inkludering, er viktig kunnskap for alle kroppsøvingslærere og skoleledere. Ved hjelp av intervjuer med seks utvalgte kroppsøvingslærere fra barne- og ungdomsskoler forsøkte vi å avdekke slik kunnskap. Resultatene viser at språkproblematikk og dusjeproblematikk synes å utgjøre de største utfordringene. Når det gjelder utfordringen knyttet til språkproblematikk, viser lærerne til en unnvikelsesstrategi (unngå aktiviteter som har komplekse regler), en oversettelsesstrategi (læreren snakker engelsk eller medelever tolker) samt en tale- og visestrategi (viser samtidig som det forklares). Når det gjelder utfordringen knyttet til dusjeproblematikk, peker lærerne på viktigheten av en god dialog med hjemmet som særlig viktig for å forebygge dusjeproblematikk, men også betydningen av informasjon til både elever og foreldre om viktigheten av at elevene dusjer, blir fremhevet. Strategier om å la de minoritetsspråklige elevene få benytte lærergarderoben, eller dusje alene før eller etter de andre, fremheves også som viktig.
\end{abstract}

Nøkkelord: Kroppsøving; multikulturelle; språk; dusjing

\begin{abstract}
Knowledge about the challenges Physical Education (PE) teachers experience when including minority-language pupils in PE, as well as the strategies experienced PE teachers use to achieve optimal inclusion is important. Interviews with six selected PE teachers from primary and lower secondary schools are the empirical material for this study. The results show that problems related to language, and to take a shower after PE, appear to constitute the greatest challenges. The teachers use three different strategies to create the best possible learning situation when it comes to language challenges: an avoidance strategy (avoid activities that have complex rules), a translation strategy (the teacher speaks English or classmates interpret), and a show-and-tell strategy (demonstrate while explaining). When it comes to the challenges related to the shower, the teachers point
\end{abstract}

^Korrespondanse: Pål Lagestad, Nord universitet, Postboks 1490, 8049 Bodø. Epost: pal.a.lagestad@, nord.no

(C) 2018 P. Lagestad and I. Mestad. This is an Open Access article distributed under the terms of the Creative Commons Attribution 4.0 International License (https://creativecommons.org/licenses/by-nc/4.0/), allowing third parties to copy and redistribute the material in any medium or format and to remix, transform, and build upon the material for any purpose, even commercially, provided the original work is properly cited and states its license.

Citation: P. Lagestad and I. Mestad. "Inkludering av minoritetsspråklige elever $i$ kroppsøvingsfaget - utfordringer og strategier med utgangspunkt $i$ et lererperspektiv»Vol. 2(3), 2018, pp. 18-33. http://dx.doi.org/10.23865/jased.v2.1159 
out that it is particularly important to have a good dialogue with the home to prevent this problem from arising in the first place, but also point out that it is necessary to inform the pupils and parents about why it is important that the pupil takes the shower after PE lessons. Strategies such as allowing minority-language pupils to use the teacher's changing room or showering alone before or after the other pupils, are also highlighted as important.

Keywords: Physical education; multi-cultural; language; showering

Received: February, 2018; Accepted: September, 2018; Published: November, 2018

\section{Innledning}

I grunnskolen skal barn og unge få en opplæring der alle elever inkluderes, og som er tilpasset deres forutsetninger og evner (NOU, 2010). Inkluderingsbegrepet er krevende, både fordi det kan forstås på ulik måte og fordi det er et begrep som lett blir politisert (Olsen, 2010). I utgangspunktet ble begrepet brukt innenfor spesialpedagogikken som en politisk ambisjon om at alle elever, også de med særlige behov, skulle tilhøre samme fellesskap i skolen (Olsen, 2010). Etter hvert er begrepet også blitt vanlig innenfor flerkulturell pedagogikk, mens det i de nyeste dokumentene om grunnskolen brukes parallelt med tilpasset opplæring og som et generelt prinsipp for alle elever (Kunnskapsdepartementet, 2018a; b). I denne artikkelen benytter vi inkluderingsbegrepet slik det er operasjonalisert av Haug (2003): å oppnå en mer inkluderende virksomhet gjennom å øke fellesskapet, deltakingen og utbyttet, slik at alle elever får en undervisning som er til gagn for dem både sosialt og faglig. Det er viktig å understreke at en ved å bruke begrepet inkludering, legger ansvaret for å virkeliggjøre målet om fellesskap på skolen, og ikke på den enkelte elev. Forskning viser at den norske skolen ikke alltid har lyktes med å være inkluderende. Engen (2004) viser at tross styringsdokumentenes ambisjoner om inkludering og likeverd når det gjelder kulturelle og språklige minoriteter, har andre sider av skolepolitikk og praksis vært preget av en likhetsdiskurs som har virket i motsatt retning. Engen har særlig vist hvordan enhetsskoletanken førte til en kulturell homogenisering som resulterte i assimilering av minoriteter, heller enn inkludering og integrering. Det betyr at det har vært et misforhold mellom de overordnede politiske idealene og praksisen i skolen. For oss er det viktig at inkludering ikke betyr likhet. Vi tror tvert om at åpenhet for mangfold og forskjellighet er en forutsetning for å kunne realisere en inkluderende skole. Fandrem (2011) er opptatt av de psykologiske prosesser barn er igjennom når de flytter fra én kultur til en annen. Hun fremhever opplevelsen av tilhørighet som grunnleggende for barn som skal vokse inn i en ny kultur. Tilhørighet skapes, ifølge Fandrem, i empatiske skolemiljøer som er åpne for ulikhet og der elevene får mulighet til å mestre. Det betyr at skolen må særlig legge til rette for at flerspråklige elever kan få mestre og oppleve seg som en del av fellesskapet uten at det betyr at de må adoptere majoritetskulturen. I denne artikkelen har vi sett på hvilke strategier lærere tar i bruk for å inkludere flerspråklige elever i aktivitetene i kroppsøvingsfaget. I drøftingen vil vi vurdere om dette er strategier som vil være 


\section{P. Lagestad og I. Mestad}

inkluderende eller ikke. Det hadde vært en mulighet å kombinere lærernes stemmer med elevenes opplevelse av strategiene. Vi har ikke valgt å trekke inn elevene i dennes studien, men vi ser at det her er rom for videre forskning.

Det norske samfunnet kan kalles et flerkulturelt samfunn, med omtrent 16 prosent innvandrere (SSB, 2018). Flerkulturell kompetanse er dermed et pedagogisk verktøy av stor betydning, og kulturell kunnskap og kompetanse er viktige komponenter i en dyktig lærers undervisningsgrunnlag (Banks, 2006; Davis, 2010). Flere forskere peker nettopp på at den stadig økende andelen minoritetsspråklige elever i skolen krever at kroppsøvingslærere får en bred base av flerkulturell kunnskap og kulturelt betingede undervisningsstrategier for å sikre at alle elever finner kroppsøvingsfaget givende og motiverende (Banks, 2006; Culp \& Chepyator-Thomson, 2011; Dagkas, 2007; Grimminger, 2011; Hsu \& Chepyator-Thomson, 2010; Tannehill \& Zakrajsek, 1993). I 2000 utgjorde minoritetsspråklige knapt 5 prosent av alle barn i barnehage, mens i 2016 hadde andelen økt til i overkant av 16 prosent (SSB, 2018). Som vi forstår ut fra disse tallene, vil andelen minoritetsspråklige barn øke betraktelig i den fremtidige norske skolen. Disse barna får også dårligere resultater på nasjonale prøver, og de har større frafall fra skolen enn etnisk norske elever (SSB, 2018). I så måte er kunnskap om strategier for å inkludere minoritetsspråklige elever i kroppsøving (som i andre fag) i skolen av særlig betydning.

Minoritetsspråklige elever defineres ifølge Udir (2015) som barn som har et annet morsmål enn norsk eller samisk. Ifølge Stortingsmelding 6 (Barne-, likestillingsog inkluderingsdepartementet, 2012) kan de minoritetsspråklige deles i tre hovedgrupper: flyktninger, familieinnvandrere og arbeidsinnvandrere. En kan se for seg at kroppsøvingslærere vil kunne ha ulike utfordringer og strategier knyttet til å skulle inkludere disse gruppene i kroppsøvingsfaget. For eksempel vil en svensk elev i norsk skole være definert som minoritetsspråklig, men språklige og kulturelle utfordringer vil kunne være små - dette i motsetning til en nyankommet flyktning fra Somalia, med annen religion og kultur.

\section{Tidligere forskning}

Litteratursøk blant vitenskapelige artikler i relevante databaser tyder på at forskningen omkring læreres erfaringer med å inkludere minoritetsspråklige i kroppsøvingsfaget er mangelfull, og at det er nødvendig med mer kunnskap på dette feltet. Denne observasjonen støttes av flere forfattere (Choi \& Chepyator-Thomson, 2011; Sparks \& Butt, 1996). Dagkas, Benn og Jawad (2011) fant at kroppsøvingslærerne i deres studie oppgav at det var utfordringer knyttet til bekledning, skifting i garderobe, kjønnsblandet undervisning og svømming. Særlig synes det å være utfordringer knyttet til muslimske jenters deltakelse i kroppsøving (Benn, Dagkas \& Jawad, 2011; Dagkas mfl., 2011; Farooq \& Parker, 2009; McInerney, Davidson, Suliman \& Tremayne, 2000). Green (2008) peker på at det er utfordringer knyttet til kroppsøvingslærere og muslimske elevers religion, og dette er knyttet til aspekter som foreldres holdninger, faste gjennom ramadan, bekledning og svømming. Disse funnene støttes av studier 
med utgangspunkt i norske elever (Opsal \& Skauge, 1996; Thorsen \& Rugkåsa, 1999; Østberg, 2003). Dagkas med flere (2011) viser til at kommunikasjon mellom skole og lokalsamfunn var avgjørende for å løse disse utfordringene. Også Walseth (2013) fant at religion har betydning for muslimske jenters deltakelse i kroppsøving, og da i forbindelse med svømming og dusjing. Ingen av de norske studiene har imidlertid hatt et lærerperspektiv. I tråd med Dewey (1916) vil læreres praktiske kunnskap omkring utfordringer ved og strategier for å inkludere elever, tilegnet gjennom mange års erfaring, være viktig kunnskap på feltet.

Både Chinga-Ramirez og Solhaug (2014) og Butt og Pahnos (1995) konkluderer med å peke på at lærere i større grad reflekterer over hvordan de selv oppfatter minoritetsspråklige elever, samt hvordan de legger til rette for deres læring. Flere utenlandske studier har pekt på at mange kroppsøvingslærere har liten kunnskap om og lite erfaring med å inkludere minoritetsspråklige/flerkulturelle i kroppsøving (Choi \& Chepyator-Thomson, 2011; Dagkas, 2007; Dagkas mfl., 2011; Davis, 2010; Sparks \& Butt, 1996). Det er grunn til å anta at disse utfordringene og denne mangelen på kunnskap også kan kjennetegne mange kroppsøvingslærere i den norske skolen. Forskning tyder på at kroppsøvingslærere med erfaring i å inkludere minoritetsspråklige besitter kunnskap som vil kunne være særlig viktig for fremtidige kroppsøvingslærere (Dagkas, 2007; Harrison, Carson \& Burden, 2010). Å innhente og dokumentere slik kunnskap vil være viktig for at disse lærerne skal kunne tilrettelegge undervisningen best mulig. Med bakgrunn i diskusjonen over vil denne studien besvare følgende problemstillinger:

(1) Hvilke utfordringer opplever kroppsøvingslærere i forbindelse med å inkludere elever med minoritetsspråklig bakgrunn i kroppsøvingsfaget?

(2) Hvilke strategier benytter kroppsøvingslærere for å inkludere minoritetsspråklige elever i kroppsøvingsfaget?

\section{Metode}

\section{Design}

Utgangspunktet for den metodiske tilnærmingen var å få tak i den felles opplevelsen eller erfaring som kroppsøvingslærerne hadde når det gjaldt utfordringer med å inkludere minoritetsspråklige i kroppsøving, samt strategier for å inkludere disse elevene (Postholm, 2010). Med et slikt perspektiv er det sentralt at forskeren får tak $i$ disse opplevelsene og erfaringene gjennom en samtale med kroppsøvingslærere. For å belyse problemstillingene og få frem kroppsøvingslærernes erfaringsbaserte kunnskap ble det gjennomført en intervjustudie med bruk av et dybdeintervju med seks kroppsøvingslærere i barne- og ungdomsskolen.

\section{Utvalg}

I tråd med Dagkas (2007) og Harrison, Carson og Burden (2010) var det en forutsetning at lærerne hadde erfaring $\mathrm{i}$ å undervise kroppsøving på barne- eller 


\section{P. Lagestad og I. Mestad}

ungdomsskoler med et stort innslag av minoritetsspråklige elever. Det var også et kriterium at lærerne underviste som kroppsøvingslærere i en stor andel av lærerstillingen. På forhånd ble det undersøkt hvilke skoler i en utvalgt større by i Norge som hadde en høy andel minoritetsspråklige elever, og tre av disse skolene ble tilfeldig valgt ut ved loddtrekning. Det ble valgt ut lærere av begge kjønn fra én ungdomsskole og to barneskoler. To av de tre skolene var mottaksskoler, og alle skolene hadde mellom 20 og 30 prosent minoritetsspråklige elever. To kroppsøvingslærere fra hver skole som tilfredsstilte kriteriene ble valgt ut ved loddtrekning. Erfaringen og utdanningsbakgrunnen varierte mellom de seks informantene, fra tre til 15 års praksis, og fra halvårsenhet til master i kroppsøving. Variasjonen i utdanning og arbeidserfaring blant deltakerne i studien vil trolig ha betydning for hvordan man opplever utfordringer knyttet til inkludering av minoritetsspråklige elever, samt hvilke strategier man har utarbeidet for å møte disse. På en annen side reflekterer svarene mange av de utfordringer og strategier som kan tenkes å være til stede blant lærere ved andre skoler, hvor utdanning og arbeidserfaring vil variere blant lærerne i kroppsøving.

\section{Innsamling av empiri}

I utformingen av intervjuguiden ble det valgt en induktiv tilnærming, da det syntes formålstjenlig å bruke åpne spørsmål for å få frem de erfaringene som kroppsøvingslærerne hadde omkring problemstillingene. Spørsmålene ble organisert i en semistrukturert intervjuguide. Intervjuene fant sted på forskningsdeltakernes arbeidsplass etter informantenes ønske. Hver informant ble intervjuet én gang, og intervjuene tok omtrent 60 minutter. Gjennomføringen av studien var godkjent av personvernombudet for forskning (NSD).

\section{Analyse av data}

Intervjuene ble transkribert og videre analysert $\mathrm{i}$ analyseprogrammet NVivo - et program som bidrar til oversikt og struktur av de analytiske funnene (Klemp, 2012). Intervjuene ble analysert ved hjelp av kategorier med utgangspunkt $\mathrm{i}$ analyse av meningsinnhold, som er en egnet tilnærming når en ønsker en beskrivelse og en forståelse av et fenomen (Johannessen, Tufte, \& Kristoffersen, 2006). Datamaterialet sorteres etter disse kategoriene for å avdekke lignende utsagn, mønstre, fellestrekk, sammenhenger eller forskjeller. På denne måten blir det sorterte datamaterialet undersøkt for å identifisere meningsfulle mønstre. Lærerintervjuene ble transkribert og tolket hver for seg. Den transkriberte teksten ble lest gjennom flere ganger, og underveis ble det laget kategoriseringer ut fra tolkninger av lærernes utsagn. Dette resulterte i de to hovedkategoriene «språkutfordringer» og "dusjeutfordringer». Datamaterialet som var sortert under hver enkelt hovedkategori, ble deretter kodet på nytt i underkategorier som omhandlet strategier. Når det gjaldt språkutfordringer, var resultatet av analysene de tre underkategoriene "unnvikelsesstrategier», "oversettelsesstrategier» og «tale- og visestrategier». Når det gjaldt dusjeutfordringer, var 
resultatet av analysene de tre underkategoriene «overtalelsesstrategi», «informasjon» og «dusje alene». På bakgrunn av problemstillingene og forholdsvis få informanter, ble det ikke funnet formålstjenlig å forsøke å skille utfordringer og strategier til informantene i forhold til variasjonen i utdanning og arbeidserfaring blant disse.

\section{Resultater}

I analysene kommer det frem at det er to områder lærerne særlig opplever utfordringer knyttet til. Disse kan kategoriseres som 'språklig kommunikasjon' og 'dusjproblematikk'. I det følgende vil vi presentere disse utfordringene som våre hovedfunn. Lærerne bekrefter at de minoritetsspråklige elevene oppleves som en veldig uensartet gruppe, og at dette gav ulik grad av utfordringer og ulike typer utfordringer. Utfordringene syntes likevel å være størst i forbindelse med muslimske elever som kom som flyktninger, og som hadde vært kort tid i Norge. Studiens resultater vil konsentrere seg om de utfordringene og strategiene som kroppsøvingslærerne hadde $\mathrm{i}$ møte med minoritetsspråklige elever, og i så måte er det først og fremst ikke-vestlige minoritetsspråklige elever som berøres.

\section{Utfordringer knyttet til språklig kommunikasjon}

Resultatene viser at lærerne selv fremhevet viktigheten av å integrere minoritetsspråklige elever i kroppsøving, og at den største utfordringen gjaldt språk blant alle de minoritetsspråklige elevene som ikke forstod norsk. Enkelte av lærerne opplevde disse utfordringene som særlig store når elevene heller ikke behersket engelsk. Disse funnene er i tråd med det vi antydet i innledningen. Her er det som nevnt viktig å fremheve at betegnelsen minoritetsspråklige elever viser til elever som er integrert $i$ det norske samfunnet og språket i ulik grad, noe alle lærerne påpekte. Jo større den kulturelle avstanden var mellom opprinnelseslandet og Norge, jo større syntes de språklige utfordringene å være. De opplevde utfordringene syntes å avta med økt erfaring. Hvor lang tid elevene hadde vært i Norge, syntes også å ha stor betydning for hvor store utfordringene ble oppgitt å være.

\section{Tale- og visestrategier}

Flere lærere påpekte at språkproblematikken var mye mindre i kroppsøving enn i andre fag, fordi de kunne vise det aller meste i kroppsøving. Nettopp det å være bevisst på og flink til å vise det en skulle gjøre, ble trukket frem som en av de viktigste strategiene knyttet til språkproblematikk. Dette gjaldt blant annet når elevene skulle lære teknikker (som en fotballpasning eller fingerslag i volleyball), gjennomføre en hinderløype (hvor læreren viste hvordan de ulike hinder skulle forseres ved hjelp av egen kropp), eller en styrketreningssirkel, hvor lærerne i tillegg til å bruke seg selv som øvingsbilde, ofte brukte andre elever som kunne øvelsene til å vise de andre elevene hva de skulle gjøre. Også det å være tydelig og forklare sakte for de minoritetsspråklige, gjerne med gjentakelse, ble fremhevet som viktig. 


\section{P. Lagestad og I. Mestad}

\section{Oversettelsesstrategier}

Flere av lærerne pekte også på at det å dra nytte av dem som forstod litt norsk, var en annen god strategi ved språkutfordringer. Dette ble gjort ved å be elever som snakket elevens morsmål, om hjelp til å forklare andre elever hva som ble sagt.

Informantene hadde ulike tilnærminger til valg av språk, fra bare å prate norsk på den ene siden, til for det meste å prate engelsk. En lærer problematiserte at mange av de minoritetsspråklige elevene snakket morsmål hjemme, og at det dermed ble for lite norskutvikling og for lite dybde i språket de snakket på skolen. Elevene lærte da også mindre om norsk kultur. En lærer uttrykte noe som problematiserer valg av språk i kroppsøvingstimene:

Vi har et fokus på at vi skal snakke norsk fordi de som kommer til en mottaksskole, skal lære seg norsk. Begynner vi å snakke engelsk til dem, starter de med å henvende seg til oss på engelsk, og det er ikke ønskelig. De må lære seg norsk så fort som mulig for å henge med. Det kan jo være en utfordring. Jeg forklarer på norsk og viser ofte i praksis, og det er ofte mer enn nok.

\section{Unnvikelsesstrategier}

Flere lærere trakk inn at regler kunne være kompliserte å forstå for minoritetsspråklige elever. Å bruke litt mer tid i begynnelsen for å forsikre seg om at alle elevene hadde forstått de enkleste reglene, ble derfor trukket frem som viktig. "En må tenke strategisk slik at elevene får et bilde av hva som skal skje i timen, for å være sikre på å ha med flest mulig», slik en lærer uttrykte det. «Om ikke ville de veldig fort bli stående og ikke tørre å være med, og bli overkjørt av andre». Et par av lærerne opplevde utfordringene knyttet til aktiviteter med mange regler så problematisk for minoritetsspråklige elever at de valgte bort slike øvelser. Som en lærer uttrykte: «Jeg tar ikke de vanskeligste aktivitetene hvor det er mye informasjon. Aktiviteter som capture the flag tar jeg for eksempel ikke, for der er det veldig mye regler å forholde seg til. Så enkelte ting velger en bort».

\section{Utfordringer knyttet til dusjing og avkledning i garderobe}

Fem av de seks lærerne trakk frem at de opplevde utfordringer med minoritetsspråklige elever når det gjaldt dusjing og skifte av klær, og at denne problematikken var større blant minoritetsspråklige enn blant etnisk norske. Her syntes religion å spille en sentral rolle, da det var blant muslimske elever at kroppsøvingslærerne opplevde disse utfordringene. Flere lærere fremhevet at mange elever dusjet med undertøyet på, og at dette var mest utbredt blant elever med minoritetsspråklig bakgrunn. Det var også lærere som oppgav at en del minoritetsspråklige elever ikke kledde seg naken sammen med andre av samme kjønn. Mange av lærerne opplevde at dette dreide seg om forskjeller med bunn i religion og kultur. Som en lærer uttrykte det: «Det er mye mer åpent og naturlig å dusje naken med samme kjønn blant etnisk norske. Det har å gjøre med hvordan en ser på kropp, hvordan en har vokst opp, hvordan det er i hjemmet». En annen lærer fremhevet at «det er lurt å trø varsomt» når 
det gjelder dusjeproblematikk - et utsagn som kan hevdes å være representativt for informantene.

Alle informantene pekte på at dusjeproblematikken i hovedsak gjaldt begge kjønn, men at muslimske jenter opplevde dette mest problematisk.

\section{Dusje-alene-strategier}

Selv om lærerne opplevde at det å ville dusje alene var mer utbredt blant minoritetsspråklige muslimske elever enn etnisk norske, var imidlertid lærerne også opptatt av å få frem at ikke alle de minoritetsspråklige muslimske elevene ønsket å dusje alene. Analysene tydet på at strategiene knyttet til dusjeproblematikk synes å variere mellom de ulike skolene og de ulike lærerne. Videre var det flere av lærerne som uttrykte at de «strakk seg veldig langt» for å legge til rette for at minoritetsspråklige elever fikk dusje alene, blant annet ved at de minoritetsspråklige elevene fikk benytte lærergarderoben. En annen strategi som ble trukket frem av flere lærere, var å sende inn de minoritetsspråklige elevene for å skifte og dusje før eller etter de andre elevene.

\section{Overtalelses- og informasjonsstrategier}

To lærere viste til viktigheten av å prøve å ufarliggjøre dusjeproblematikken ved å prate om dette med dusjing først i kroppsøvingstimen - sett både i sammenheng med at ingen er like, og i sammenheng med hygiene. To andre lærere viser til at de prøver en overtalelsesstrategi, der de ved hjelp av informasjon til elever og foreldre ønsker å få dem til å forstå hvorfor det er nødvendig at elevene dusjer. Flere av lærerne trakk frem betydningen av å sende ut et felles skriv til foreldrene om dusjing, der foreldrene meldte tilbake om elevene skulle dusje eller ikke og dermed ble ansvarliggjort:

Da har jeg lagt ansvaret til foreldrene. Da har jeg sendt ut et skriv hvor jeg informerer om dette med hygiene, og om at jeg vil ha deres godkjennelse på at eleven skal dusje eller ikke dusje etter gymmen. Da har jeg det skriftlig. Det fungerer veldig godt.

Som en annen lærer sa: «Så lenge de har med melding hjemmefra om at sånn skal det være, er det greit for oss». Samtidig peker denne læreren på at dette ikke er helt uproblematisk, da elevene er pålagt å dusje nakne før svømming [hvor det ikke finnes lærergarderobe å låne dem], og at dette fører til at «noen er borte hver gang det er svømming, da, og det kan jo ha noe med det å gjøre».

\section{Diskusjon}

Resultatene tyder på at språkproblematikk og dusjeproblematikk synes å utgjøre de største opplevde utfordringene knyttet til inkluderingen av minoritetsspråklige elever i kroppsøving, og det synes hensiktsmessig å drøfte disse utfordringene og strategiene hver for seg. 


\section{P. Lagestad og I. Mestad}

\section{Utfordringer og strategier knyttet til språk}

Språkutfordringene som fremheves av forskningsdeltakerne, underbygger tidligere forskning hvor språkproblematikk fremstår som et sentralt tema knyttet til inkludering av minoritetsspråklige elever (Hauge, 2014; Loona, 2001). Det er imidlertid tydelig at det ikke ligger en felles strategi og kunnskap bak språktilnærmingen blant lærerne som ble intervjuet. Lærerne i vår undersøkelse er opptatt av minoritetselevers muligheter til deltakelse og læring i kroppsøvingsfaget. Selv om flere av våre informanter gir uttrykk for at denne gruppen elever klarer seg bedre i dette faget enn i andre fag siden så mange av aktivitetene er ikke-verbale, møter også kroppsøvingslærere språklige utfordringer. Det er særlig i de delene av undervisningen som inneholder instruksjoner, som ved igangsetting av ulike aktiviteter, at dette skjer. Vi finner at lærerne tar i bruk tre ulike strategier for å skape en best mulig læringssituasjon: en unnvikelsesstrategi, en oversettelsesstrategi og en tale- og visestrategi. Det er viktig å presisere at strategiene ikke beskriver tre ulike typer lærere. Flere av strategiene brukes gjerne av samme lærer og noen ganger samtidig. Lærernes kunnskap på feltet synes å være tilegnet på bakgrunn av skolepraksis etter endt utdanning - et funn som ikke synes å være belyst tidligere i kroppsøvingsforskning.

\section{Unnvikelsesstrategier}

Den første strategien er å unngå aktiviteter som har komplekse regler. Dette gjøres for å redusere språkutfordringene og på denne måten optimalisere inkluderingen av minoritetsspråklige elever i kroppsøvingsundervisning. Det kommer frem i vårt materiale at lærerne opplever at det er særlig vanskelig å forklare regler til elever med begrensede norskkunnskaper. Dette erfarer lærerne når de i aktiviteter ser at elever ikke har forstått hva de skal gjøre og derfor blir passive og usikre. Når det gjelder regler, er det en særlig tett forbindelse mellom språk og handling. Elevene skal gjøre det som sies. Da er det ikke nok å forstå ordene som sies, det kreves også at en klarer å kople fra ord til handling og at en forstår den kulturelle settingen reglene inngår i. Dette viser oss at språk er innvevd i kultur (Aamotsbakken \& Knudsen, 2011; Green, 1988). Å lære et språk er derfor å lære en kultur. Det betyr at å lære seg språk i kroppsøvingsfaget handler mye om å lære seg den norske kroppsøvingskulturen. Det krever at lærerne er språkbevisste, men også bevisste på den konteksten de bruker språket i. Unnvikelsesstrategien kan være en vei ut av vanskelige situasjoner både for læreren og eleven, men ønsket om å unngå problemer kan også føre til at elevene går glipp av kulturell kompetanse. Det vil bety at en slik type strategi ikke vil styrke en reell inkludering.

\section{Oversettelsesstrategier}

Den neste strategien er bruk av oversetting, enten ved at læreren snakker engelsk eller ved å bruke medelever som tolker. Bruk av engelsk forutsetter at de minoritetsspråklige elevene forstår engelsk bedre enn norsk. I materialet vårt fremstår ikke 
dette som en gjennomgående strategi hos de seks lærerne. Årsaken til det kan være at mange minoritetsspråklige elever ikke har så gode engelskkunnskaper at dette er en effektiv strategi. En viktigere årsak kan være at denne strategien ikke bidrar til å styrke elevens norskkunnskaper. Vi ser at en av våre informanter eksplisitt tar avstand fra en slik strategi fordi den forsinker elevenes opplæring i norsk. Dette viser at lærerne har bevissthet om betydningen språket har i den kontinuerlige kunnskapsformidlingen, også i et praktisk fag som kroppsøving. Hauge (2014) viser til at en del av målet for norskopplæringen er at elevene skal lære å bruke norsk til det de trenger å bruke det til. De skal lære om verden rundt seg og få kunnskaper om norsk kultur. Å lære seg norsk er også en forutsetning for å bli en del av fellesskapet i klassen.

Den andre typen oversettelse er å bruke medelever som morsmålstolker for minoritetsspråklige elever. Denne strategien forutsetter at det finnes elever med samme morsmål som elevene med svake norskkunnskaper og som har god nok kompetanse i norsk til at de kan hjelpe medeleven. En slik tilnærming er i tråd med Hauge (2014) og Loona (2001). Når skolen bygger på det språket eleven har lært hjemme, og viderefører denne begrepsutviklingen, lærer elevene de norske betegnelsene på begrepene enten parallelt eller litt senere (Hauge, 2014). Hauge (2014) fremhever betydningen av at lærerne anerkjenner og støtter elevens morsmål og kulturelle bakgrunn, og at dette dreier seg om hvorvidt man opplever elevens bakgrunn som en ressurs eller et problem for skolen. Loona (2001) problematiserer forholdet mellom ensretting eller mangfold i språket, og utdyper betydningen av å bruke morsmål som en ressurs i skolen. Loona påpeker videre at det ofte hevdes at gode norskkunnskaper er nøkkelen til integrering av innvandrere, men enda viktigere er det at integrering er nøkkelen til utvikling av gode språkkunnskaper.

Av resultatene forstår vi at enkelte lærere dermed har en mangelfull forståelse av hvordan språk læres når de kun tillater norsk i kroppsøvingstimene. Det samme ser vi når enkelte forventer at elevene snakker norsk hjemme. I følge forskning gir et godt fungerende morsmål elevene bedre forutsetninger for å lære seg norsk. Når denne studien viser at en del lærere fremhever at de aktivt bruker andre elever til å forklare hva læreren skal gjøre, på elevens morsmål, er det grunn til å tro at dette vil styrke både elevenes utbytte av kroppsøvingsundervisningen og språklæring (Loona, 2001).

\section{Tale- og visestrategier}

Den siste strategien vi møter i materialet vårt, er en tale- og visestrategi. Her viser lærerne hvordan ulike øvelser skal gjøres, samtidig som de tydelig forklarer ved å bruke norsk språk. Flere lærere understreker at dette krever at de er bevisste på hvilke ord de bruker og at de ofte må snakke saktere enn det som er naturlig. En slik tilnærming er lettere å få til i et praktisk fag som kroppsøving, slik også lærerne fremhever, og på denne måten kan en argumentere for at kroppsøvingsfaget kan være en god arena for språkutvikling blant minoritetsspråklige elever. Det er også mulig å argumentere for at denne tilnærmingen er helt nødvendig i et fag som kroppsøving. I følge Michael Polanyi (1968) er en del av den menneskelige kunnskapen taus. Det vil si at 


\section{P. Lagestad og I. Mestad}

vi ikke klarer å uttrykke kunnskapen verbalt fordi den er ureflektert og tas for gitt i våre kroppslige handlinger (Polanyi, 1968). Det er altså grunn til å tro at mange aktiviteter i kroppsøvingsfaget, kulturelt og kroppslig, tas for gitt både av lærere og majoritetselever. I møtet med minoritetsspråklige elevers begrensede språkkunnskaper og manglende sosialisering inn i norsk kroppsøvingskultur, blir denne kunnskapen som har vært uartikulert, synlig på en ny måte. Å bruke kroppen til å vise øvelser samtidig som læreren forklarer hva som skjer på norsk, kan være en god måte å hjelpe elevene til å forstå og mestre det som er nytt og ukjent.

Kroppsøvingslærerne i vårt materiale opplever språklige utfordringer i undervisningen av minoritetsspråklige elever med kort botid i Norge. Vi har sett at våre forsknings deltakere har utviklet et repertoar av strategier for å møte denne utfordringen. Det ser imidlertid ut som at strategiene er utviklet gjennom erfaring, og at det er lite faglig kunnskap og refleksjon bak valgene. Flerkulturell eller interkulturell kompetanse består både av erfaring, fagkunnskap og refleksjon (Bøhn \& Dybedahl, 2017). De lærerne vi har intervjuet har mye erfaring, men det er mye som tyder på at de trenger å styrke sin språkkompetanse. I den norske skolen har alle fag ansvar for elevens språkopplæring. Selv om kroppsøvingsfaget er et fag der andre uttrykk enn det rent verbale har en viktig plass, og at akkurat dette kan fremme inkludering av minoritetsspråklige elever, trenger også kroppsøvingslærere kunnskap om hvordan språk læres og utvikles. I møte med flerspråklige elever blir dette særlig tydelig.

\section{Utfordringer og strategier knyttet til dusje- og garderobeproblematikk}

Den andre utfordringen våre forskningsdeltakere trekker frem i møte med minoritetselever, er knyttet til dusjing og deling av garderobe. I vårt materiale legger informantene størst vekt på utfordringen med fellesdusj. Ønsket om kjønnssegregering i kroppsøvingsfaget og da særlig i svømming fra minoritetselever eller deres foresatte, har sammenheng med normer knyttet til seksualitet, påkledning og anstendighet i islam. Det betyr at dette er normer som blir viktige for flere først i forbindelse med puberteten. Mye tyder på at dette i større grad enn dusjing, er en utfordring for jenter mer enn gutter (Otterbeck, 2000). Også Walseth (2013) fant at den norske modellen med kjønnsblandet svømmeundervisning var noe problematisk for muslimske jenters deltakelse i svømming, og at dette skyldtes religion.

\section{Dusje alene-strategier}

Resultatene viser at lærerne opplevde at en del av de minoritetsspråklige elevene i større grad enn etnisk norske ønsket å dusje alene. Dette gjelder i hovedsak enkelte muslimske elever. Funnene våre samsvarer med funn som vi har i tidligere forskning på feltet (Benn mfl., 2011; Dagkas mfl., 2011; Farooq \& Parker, 2009; Green, 2008; McInerney mfl., 2000; Opsal \& Skauge, 1996; Thorsen \& Rugkåsa, 1999; Østberg, 2003; Walseth, 2013). Bakgrunnen for denne utfordringen ligger i det islamske prinsippet om awra, eller 'skambelagt' nakenhet (Shavit \& Winter, 2011). I følge tradisjonell islam skal en ikke vise seg naken for andre enn sin ektefelle. Dette er et islamsk 
prinsipp knyttet til bluferdighet, og gielder begge kjønnene. Mange muslimske barn lærer derfor fra barnehagealder å dekke seg til når de er sammen med andre (Eidhamar, 2014). Samtidig må det påpekes at resultatene viser at ikke alle de minoritetsspråklige muslimske elevene ønsker å dusje alene, og at de fleste minoritetsspråklige elevene dusjer sammen med de andre elevene. Dette viser at muslimsk praksis ikke er entydig. Tilhørighet til ulike kulturelle og religiøse tradisjoner, samt personlige valg og vurderinger, har betydning for den enkelte muslims praksis.

Lærerne nevner strategiene å la elevene dusje i lærergarderoben, eller å la de aktuelle elevene dusje enten før eller etter resten av elvene. Dette er strategier som anbefales av Opsal og Skauge (1996) for å løse dusjeproblematikken. De foreslår som løsninger å skifte klær før eller etter de andre, å henge opp forheng i dusjen, å låne ut lærergarderober og å la de muslimske elevene dusje etter de andre. Egne dusjer med mulighet for å skifte tøy blir foreslått som den beste løsningen. Om dette ikke er mulig, bør en ifølge Opsal og Skauge kombinere løsningene. I denne sammenheng er det også viktig å påpeke at felles dusjing er noe som kan være problematisk for alle elevgrupper, også etnisk norske elever (Wabakken, 2010).

\section{Overtalelses- og informasjonsstrategier}

Walseths (2013) resultater viser at dusjeproblematikken synes å være til stede blant begge kjønn, men mest hos jenter. Dette kan forklares ved at skillet mellom kjønnene følges opp mye strengere for jenter enn for gutter blant muslimer (Østberg, 2003; Ottebeck, 2000). Østberg fremhever at det ofte er jentene som er bærere av idealene om renhet og ære i den muslimske tradisjonen. Vår undersøkelse viser at lærerne møter denne utfordringen med ulike strategier, delvis i kombinasjon. To av lærerne forteller at de prøver en overtalelsesstrategi. Det vil si at de ved hjelp av informasjon skal få elever og foreldre til å forstå hvorfor det er nødvendig at elevene dusjer. Utfordringen med denne strategien er at den ikke tar høyde for den egentlige årsaken til at elevene ikke dusjer. Det er ikke foreldrenes mangel på kunnskap om hygiene som fører til utfordringen, men religiøse verdier og praksiser.

Retningslinjer fra Utdanningsdirektoratet (Udir, 2014) viser til at dersom dusjing er en utfordring for den enkelte, er det viktig at skolen ikke griper inn i enkeltelevers integritet på en måte som ikke fremmer deres helse, trivsel og læring, jf. opplæringsloven $₫ 9 \mathrm{a}-1$. Dette betyr at det i prinsippet er foreldrene, eventuelt sammen med elevene, som avgjør om elevene skal dusje. Resultatene våre tyder på at mange av lærerne la til rette for en god dialog mellom lærere og foreldre når det gjaldt dusjing, blant annet giennom å benytte skriv til foreldrene der de skulle ta stilling til om barnet skulle dusje, og da eventuelt i lærergarderoben.

Fandrem (2011) understreker hvor viktig et godt samarbeid med hjemmet er for at inkludering av elever med minoritetsbakgrunn skal lykkes. En slik dialog må, ifølge Fandrem, baseres på at skole og foreldre blir bevisste på at de har felles interesser og verdier knyttet til elevene. Dette er særlig aktuelt når vi kommer til utfordringen med svømmeundervisning. I motsetning til dusjing er det ikke opplagt at 


\section{P. Lagestad og I. Mestad}

svømmeopplæring er frivillig i den norske skolen. I følge opplæringsloven $\int 2-3 a$ kan foreldre, eller elever over 15 år, be om «fritak frå dei delar av undervisninga ved den enkelte skolen som dei ut frå eigen religion eller eige livssyn opplever som utøving av ein annan religion eller tilslutning til eit anna livssyn, eller som dei på same grunnlag opplever som støytande eller krenkjande» (Opplæringslova 2-3a). De kan imidlertid ikke be om fritak fra kunnskap i de ulike emnene. I et fag som kroppsøving kan det diskuteres om kunnskap og ferdigheter er så sammenvevd at det blir meningsløst å si at en når kompetansemålene knyttet til svømming ved å kun ha kunnskap om aktiviteten. En god dialog med foreldrene kan også her gi resultat. Dette kan for eksempel bety at foreldrene eller andre foresatte får kunnskap om hvorfor det er viktig å lære seg å svømme i Norge. På den måten kan en etablere et interessefellesskap rundt barnets helse og trygghet. En mangelfull dialog mellom skole og hjem i forbindelse med svømmeundervisning ble påvist i en studie av Giæver (2010), med negativt utfall. En av informantene sa at hun har gått glipp av svømmeundervisning fordi læreren ikke var klar over at foreldrene trengte informasjon om hva undervisningen gikk ut på. Dagkas med flere (2011) fant at kommunikasjon mellom skole og foreldre var avgjørende om en skulle løse utfordringene knyttet til muslimske jenters deltakelse i kroppsøving.

\section{Styrker og svakheter ved studien}

Resultatene av studien uttrykkes gjennom seks kroppsøvingslæreres opplevelser, meninger og tolkninger, noe som gjør at resultatene ikke kan generaliseres. Resultatene kan imidlertid ha en allmenngyldig verdi, som en overføringsverdi for andre lærere i skolen (Postholm, 2010). I så måte tilfører studien ny kunnskap ut fra en systematisk analyse av hvilke strategier som lærere på skoler med en stor andel minoritetsspråklige benytter for å løse disse utfordringene. At de seks kroppsøvingslærerne synes å være forholdsvis unisone i sin opplevelse av språk- og dusjeproblematikk, styrker påliteligheten og troverdigheten av resultatene. Som nevnt vil variasjonen $\mathrm{i}$ utdanning og arbeidserfaring blant deltakerne i studien trolig ha betydning for hvordan man opplever utfordringer knyttet til inkludering av minoritetsspråklige elever. På en annen side vil informantenes opplevelser, uavhengig av utdanning og arbeidserfaring, være fruktbare for å forstå denne problematikken.

Ved å velge et lærerperspektiv utelates elevenes opplevelser og erfaringer på området. På en annen side var formålet å avdekke erfarne læreres refleksjoner omkring utfordringer og strategier knyttet til inkludering av minoritetsspråklige elever. Denne kunnskapen kan bidra til å gjøre fremtidige lærere mer bevisste på hvilke utfordringer de kan møte, samt vise til strategier for å inkludere minoritetsspråklige elever - noe forskere har pekt på som viktig (Butt \& Pahnos, 1995; Chinga-Ramirez \& Solhaug, 2014). I et etisk perspektiv er det grunn til påpeke at selv om resultatene er anonymiserte og ikke er sensitive, blir forskningsdeltakernes svar tolket og drøftet i et kritisk lys i denne studien. En slik bearbeiding og analyse av informantenes svar var imidlertid forespeilet informantene før datainnsamlingen fant sted. 


\section{Konklusjon}

Resultatene viser at språkproblematikk og dusjeproblematikk synes å utgiøre de største utfordringene når det gjelder inkludering av minoritetsspråklige elever i kroppsøvingsfaget, og underbygger dermed andre studier når det gjelder hvilke utfordringer lærere opplever når det gjelder inkludering av minoritetsspråklige elever. Studien kommer frem til ny kunnskap når det gjelder en systematisk analyse av hvilke strategier som det ut fra et lærerperspektiv blir brukt for å løse disse utfordringene. Vi finner at lærerne tar i bruk tre ulike strategier for å skape en best mulig læringssituasjon i forhold til språklige utfordringer: en unnvikelsesstrategi, en oversettelsesstrategi og en tale- og visestrategi. I forhold til dusjeproblematikk, fremhever lærerne gjennom en overtalelsesstrategi viktigheten av en god dialog med hjemmet, samt gjennom en informasjonsstrategi til både elever og foreldre viktigheten av at elevene dusjer. Videre viser lærerne til en strategi om å la elevene få dusje alene, gjennom å la minoritetsspråklige få benytte lærergarderoben eller dusje alene før eller etter de andre som strategier. I tråd med forskning fra andre land (Choi \& Chepyator-Thomson 2011; Dagkas 2007; Dagkas mfl. 2011; Davis 2010; Sparks \& Butt 1996) indikerer resultatene i denne studien at ikke alle kroppsøvingslærere har nok kunnskap om inkludering av minoritetsspråklige elever. I samsvar med funnene til Choi og Chepyator-Thomson (2011) tyder resultatene på at inkludering av minoritetsspråklige i skolen i enda større grad bør være et tema i lærerutdanningen, da kunnskapen til informantene synes å være varierende og tilfeldig. At lærernes kunnskap på feltet synes å være tilegnet på bakgrunn av skolepraksis etter endt utdanning, er et funn som ikke er belyst tidligere i kroppsøvingsforskning. Ved å ikke inkludere et elevperspektiv i studien, får en ikke frem kunnskap om hvordan elevene opplever utfordringer og strategier. Det vil således være viktig å følge opp denne studien med en studie som belyser kroppsøvingslæreres utfordringer og strategier knyttet til inkludering av minoritetsspråklige elever, sett fra et elevperspektiv. Her kan en også se for seg intervensjon, hvor de ulike strategiene blir testet ut, og elevenes erfaringer når det gjelder disse blir belyst.

\section{Forfatteromtale}

Pål Lagestad er professor i kroppsøving og idrett ved fakultet for lærerutdanning, kunst og kulturfag, Nord universitet.

Ingvild Mestad er stipendiat i kristendom, religion, livssyn og etikk ved fakultet for lærerutdanning, kunst og kulturfag, Nord universitet.

\section{Referanser}

Amotsbakken, B., \& Knudsen, S. V. (2011). A tenke teori. Om lesing og lesestrategier. Oslo: Gyldendal Akademisk. Banks, J. (2006). Cultural diversity and education: Foundations, curriculum, and teaching. New York: Pearson.

Barne-, likestillings- og inkluderingsdepartementet (2012). Stortingsmelding nr. 6. en helhetlig integreringspolitikk. Mangfold og fellesskap. Nedlastet 8. juli 2015 fra: https://www.regjeringen.no/no/dokumenter/meld-st-6-20 122013/id705945/ 


\section{P. Lagestad og I. Mestad}

Benn, T., Dagkas, S., \& Jawad, H. (2011). Embodied faith: Islam, religious freedom and educational practices in physical education. Sport, Education and Society, 16(1), 17-34.

Butt, K. L., \& Pahnos, M. (1995). Multicultural education: Why we need multicultural focus in our schools. Fournal of Physical Education, Recreation E Dance, 66(1), 48-53.

Bøhn, H., \& Dybedahl, M. (2009). Veien til interkulturell kompetanse. Bergen: Fagbokforlaget.

Charmaz, K. (2006). Constructing Grounded Theory. A Practical Guide Through Qualitative Analysis. London: Sage.

Chinga-Ramirez, C., \& Solhaug, T. (2014). Jeg er annerledes! - en diskusjon av erfaringer med å være annerledes i den norske skolen (s. 217-239). I K. Westrheim og A. Tolo (Red.), Kompetanse for mangfold. Om skolens utfordringer $i$ det minoritetsspråklige Norge. Bergen: Fagbokforlaget.

Choi, W., \& Chepyator-Thomson, R. (2011). Multiculturalism in Teaching Physical Education. Fournal of Research, 6(2), 14-20.

Culp, B., \& Chepyator-Thomson, R. (2011). Examining the Culturally Responsive Practices of Urban Primary Physical Educators. Physical Educator, 68(4), 234-253.

Dagkas, S. (2007). Exploring teaching practices in physical education with culturally diverse classes: a crosscultural study. European fournal of Teacher Education, 30(4), 431-443.

Dagkas, S., Benn, T., \& Jawad, H. (2011). Multiple voices: improving participation of Muslim girls in physical education and school sport. Sport, Education and Society, Til forfatter: sjekke dnene referansen: I alle søk på denne tittelen finner jeg at det står: 16(2), 223-239.

Davis, K. (2010). Physical educators must address diversity now! fournal of Physical Education, Recreation $\mathcal{E}$ Dance, 81(2), 4-5.

Dewey, J. (1916). Democracy and Education. An introduction to the Philosophy of Education. New York: The Free Press.

Eidhamar, G. L. (2014). Små barn - stort mangfold. Oslo: Cappelen Damm Akademisk.

Engen, T. O. (2004). Tilpasset opplæring for majoritets- og minoritetsbarn under L97. I K. J. Solstad og T. O. Engen (Red.), En likeverdig skole for alle? Om enhet og mangfold i grunnskolen. Oslo: Universitetsforlaget.

Fandrem, H. (2011). Mangfold og mestring i barnehage og skole: migrasjon som risikofaktor og ressurs. Kristiansand: Høyskoleforlaget.

Farooq, S., \& Parker, A. (2009). Sport, Physical Education and Islam: Muslim Independent Schooling and the Construction of Masculinities. Sociology of Sport fournal, 26(2), 277-295.

Green, B. (1988). Subject-specific Literacy and School learning: A Focus on Writing. Australian fournal of Education, 32(2), 156-179.

Green, K. (2008). Understanding Physical Education. London: Sage.

Grimminger, W. (2011). Intercultural competence among sports and PE teachers. Theoretical foundations and empirical verification. European fournal of Teacher Education, 34(3), 317-337.

Haug, P. (2003). Regimer i forskning om spesialundervisning i Norge. Psykologisk Pcedagogisk Rådgivning, 40(2), 181-205.

Hauge, A-M. (2014). Den felleskulturelle skolen. 3. utgave. Oslo: Universitetsforlaget.

Harrison, L., Carson, R. L., \& Burden, J. (2010). Physical Education Teachers' Cultural Competency. Fournal of Teaching in Physical Education, 29(2), 184-198.

Hsu, S-H., \& Chepyator-Thomson, R. (2010). Multiculturalism in Secondary School. Physical Education Textbooks. Fournal of Teaching in Physical Education, 29(2), 199-220.

Johannessen, A., Tufte, P. A., \& Kristoffersen, L. (2006). Introduksjon til samfunnsvitenskapelig metode. 3.ugave. Oslo: Abstrakt forlag.

Kunnskapsdepartementet (2018a). Fag - Fordypning - Forståelse - En fornyelse av Kunnskapsløftet. Meld. St. 28 (2015-2016). Nedlastet 14. mai fra https:/www.regjeringen.no/no/dokumenter/meld.-st.-28-20152016/ id2483955/

Kunnskapsdepartementet (2018b). Larelyst - tidlig innsats og kvalitet $i$ skolen. Meld. St. 21 (2016-2017). Nedlastet 14. mai fra https://www.regjeringen.no/no/dokumenter/meld.-st.-21-20162017/id2544344/

Loona, S. (2001). Tospråklighet. I T. H. Eriksen (Red.), Flerkulturell forståelse (2. utgave s. 213-239). Oslo: Universitetsforlaget.

McInerney, D. M., Davidson, N., Suliman, R., \& Tremayne, B. (2000). Personal Development, Health and Physical Education in Context: Muslim and Catholic Perspectives. Australian fournal of Education, 44(1), 26-42.

Olsen, M. H. (2010). Inkludering: Hva, hvordan og hvorfor. Bedre skole, 3, 58-63.

Opsal, J., \& Skauge, I. L. (1996). Muslimske elever i norsk skole: en ressursbok for lcerere. Oslo: Kulturbro Forlag.

Otterbeck, J. (2000). Islam, muslimer och den svenska skolen. Lund: Studentlitteratur. 
Postholm, M. B. (2010). Kvalitativ metode: en innføring med fokus på fenomenologi, etnografi og kasusstudier. Oslo: Universitetsforlaget.

Shavit, U., \& Winter, O. (2011). Sports in Contemporary Islamic Law. Islamic Law and society, 18(2), $250-280$. Skjelbred, D., \& Aamotsbakken, B. (2003). DEL 2. Bakgrunn. I D. Skjelbred og B. Aamotsbakken (Red.). Det flerkulturelle perspektivet i larebøker og andre leremidler. Sluttrapport til forfatter: sett inn Hentet fra og dato http://www.udir.no/Tilstand/Forskning/Rapporter/Hogskoler/Det-flerkulturelle-perspektivet-i-larebokerog-andre-laremidler-2003/

Sparks, W. G., \& Butt, K. L. (1996). Multicultural education in physical education: A study of knowledges, attitudes and experiences. Physical Educator, 53(2), s. 73-87.

SSB (2013). Statistisk sentralbyrå i Norge.

SSB (2018). Hvordan går det med innvandrere og deres barn i skolen? Nedlastet 11.april fra https://www.ssb. no/utdanning/artikler-og-publikasjoner/hvordan-gar-det-med-innvandrere-og-deres-barn-i-skolen

Tannehill, D., \& Zakrajsek, D. (1993). Student Attitudes Towards Physical Education: A Multicultural Study. Fournal of Teaching in Physical Education, 13(4), 78-84.

Thorsen, K. T., \& Rugkåsa, M. (1999). Spør oss! En systematisering av Islams Kvinnegruppe Norge og deres løsningsorienterte metoder i arbeid blant muslimske jenter og kvinner. Oslo: DOXA antropologisk byrå.

Utdanningsdirektoratet (2015). Nyttige begreper. Nedlastet 8. juli 2015 fra: http://www.udir.no/Spesielt-for/ Minoritetsspraklige-elever/Minoritetsspraklige---nyttige-begreper/Nyttige-begreper/

Wabakken, T. V. (2010). Et følelsesladet valg. Om prosesser og mekanismer bak ikke deltakelse i kroppsøving, dusj og garderobeaktiviteter. Masteroppgave. Porsgrunn: Høgskolen i Telemark.

Walseth, K. (2013). Muslim girls' experiences in physical education in Norway: What role does religiosity play? Sport, Education and Society 20(3), 304-322.

Østberg, S. (2003). Muslim $i$ Norge. Religion og hverdagsliv blant unge norsk-pakistanere. Oslo: Universitetsforlaget. 